\title{
That Woman from Michigan: How Gender Resentment Shapes the Efficacy of Stay-at-Home Policies
}

Nicole Kalaf-Hughes

Bowling Green State University

Debra Leiter

\section{University of Missouri-Kansas City}

The United States has the highest number of COVID-19 cases, yet many Americans have responded indifferently toward policies designed to combat the spread of the virus. While nearly all 50 states have implemented some type of stay-at-home policy to encourage social distancing, there has been high variation in the degree of compliance. We argue that this variance is partly driven by gender resentment. Gender resentment reduces trust in female political leaders and thus decreases compliance with government policy and recommendations. Using data from SafeGraph and the 2016 American National Election Study, we demonstrate that the effect of stay-at-home policies on social distancing is reduced when gender resentment increases in states with female leaders. However, when gender resentment is low, there is no difference in the effect of policies on behavior. This research has important implications for understanding unseen barriers that can mediate the efficacy of female political leaders.

Keywords: Gender resentment, state politics, COVID-19

7 he United States has more cases of COVID-19 than any other nation, 1 yet many Americans, including President Donald Trump, have ignored or challenged directives meant to contain the virus. For example, in response to criticisms levied by the Democratic governor of

Published by Cambridge University Press 1743-923X/20 \$30.00 for The Women and Politics Research Section of the American Political Science Association.

(c) The Author(s), 2020. Published by Cambridge University Press on behalf of The Women and Politics Research Section of the American Political Science Association. This is an Open Access article, distributed under the terms of the Creative Commons Attribution licence (http://creativecommons.org/licenses/by/4.0/), which permits unrestricted re-use, distribution, and reproduction in any medium, provided the original work is properly cited. doi:10.1017/S1743923X20000392 
Michigan, Gretchen Whitmer, against the administration's handling of the pandemic, President Trump told voters she was "way in over her head," later calling on them to "LIBERATE MICHIGAN!"l Protests opposing Whitmer's stay-at-home orders followed, and social distancing declined. Meanwhile, Whitmer's southern neighbor, Ohio Republican governor Mike DeWine, enacted similar stay-at-home-policies, yet he saw relatively little backlash. However, Dr. Amy Acton, Ohio's director of health, who appeared with Governor DeWine at daily press conferences, garnered national attention and saw protests outside her home.

The experiences of Governor Whitmer and Dr. Acton are not unique. Across the country, female politicians have faced backlash for stay-athome-policies encouraging social distancing. ${ }^{2}$ While nearly all 50 states have implemented some restrictions, there is noticeable state-by-state variation in the degree of compliance. Why, if state governments have introduced relatively similar policies, do we see such variation in citizen response to stay-at-home orders?

We argue that one factor driving compliance with social distancing policies is the politics of gender resentment. Resentment captures the idea a group is getting more than it deserves (Kinder and Sanders 1996). Gender resentment is an expression of hostile sexism (Glick and Fiske 1996) that does not necessarily emphasize biological inferiority but instead sees women as figures who have attained their status less through their own efforts and more through special treatment and unequal application of rules (Banks and Valentino 2012; Jennings 2006). ${ }^{3}$ These hostile attitudes toward women "cutting men out" and not "knowing their place" lead to anger, mistrust, and lower evaluations of female leaders (Masser and Abrams 2004; Valentino, Wayne, and Oceno 2018). Gender resentment, similar to racial resentment, has grown in the last four decades, based on a common perception that "gender equality... [was] more or less achieved" and increasing competition between men and women over economic and political opportunity (Jennings 2006, 210). Resentment, which is exacerbated by anger and fear, would be heightened by the uncertainty and ire associated with the pandemic (Banks and Valentino 2012).

1. March 27, 2020 (https://twitter.com/realdonaldtrump/status/1243726993537073152?lang=en) and April 17, 2020 (https://twitter.com/realDonaldTrump/status/1251169217531056130).

2. Stay-at-home policies include shelter-in-place orders and other directives designed to encourage social distancing.

3. There is a debate in the literature about the degree to which resentment is a distinct attitude from conservatism. While there is a correlation between racial resentment and conservativism, Wallsten et al. (2017), in examining payment for NAACP athletics, demonstrate that resentment does distinctly drive policy preferences associated with anti-black bias. 
We argue that female leaders, faced with gender resentment, will find citizens less willing to comply with state mandated stay-at-home orders. Stay-at-home-policies designed to encourage social distancing require high levels of public trust and belief in government policy, as the benefit to most people is essentially invisible, while the costs are great (Hetherington and Globetti 2002). The uncertainty, fear, and anger surrounding the pandemic should both exacerbate gender resentment and erode the trust in female leaders. In turn, the willingness of citizens to comply declines drastically and, under the highest levels of gendered animosity, may incentivize some not to comply as a form of protest.

Gender resentment should not be taken as given; there is high variance in gender resentment across the states. We expect that male and female-led states with low gender resentment to have similar levels of compliance. Indeed, under certain circumstance, female leaders may be more effective at responding to the pandemic (Shay 2020). It is only when resentment leads to distrust and political animus that we expect compliance to decline for female leaders.

\section{DATA AND METHODS}

To explore the role of gender resentment in compliance with social distancing policies, we use (1) geolocation data from SafeGraph, (2) survey data from the 2016 American National Election Study (ANES), ${ }^{4}$ (3) the timing and location of government-sanctioned stay-at-home policies, and (4) the number of COVID-19 cases per state relative to the total population. ${ }^{5}$ We also measure whether a majority of the state voted for Donald Trump in the 2016 election, the gender and political affiliation of each state's governor, and the gender of the state-level health director. $^{6}$

To measure stay-at-home compliance, we rely on anonymized data from SafeGraph Inc. covering daily movements between January 1 and May 22, 2020. These data allow for the analysis of movement of a large, representative sample of Americans (Chen and Rohla 2018). From this data, we measure social distancing as:

Social Distance $_{s, t}=$ Completely Home $_{s, t} /$ Total Device Count $t_{s, t}-$ Working $_{s, t}$

4. American National Election Study, 2016 Pre-Election Survey, https://electionstudies.org/datacenter/2016-time-series-study/.

5. Data available from https://github.com/CEIDatUGA/COVID-19-DATA.

6. Table $\mathrm{l}$ in the appendix lists the states with female governors and female health directors. 
where Completely Home $e_{s, t}$ is the number of devices in state $s$ on day $t$ that never left home (see Painter and Qiu 2020). ${ }^{7}$ Total Device Count $t_{s, t}$ is the total number of devices in state $s$ on day $t$, and Working $s, t$ is the number of devices leaving home and going to another location for 3 to 10 hours during the period of 8 a.m. to 6 p.m. local time. ${ }^{8}$ A higher percentage of Social Distance $_{s, t}$ indicates that more residents in the state are complying with stay-at-home orders. The average for Social Distance $_{s, t}$ is $31.5 \%$ across the entire sample, $28.6 \%$ before the state policy, and $37.9 \%$ after the state policy.

To measure gender resentment, we recreate the hostile sexism index using the 2016 ANES pre-election survey (Glick and Fiske 1996; Valentino, Wayne, and Oceno 2018), asking whether respondents agree that several innocent remarks are viewed as sexist: "women fail to appreciate what men do for them," "women seek to gain power by getting control over men," and "women put men on a tight leash." The resulting index is rescaled to run between 0 and 1 , with 1 indicating higher levels of gender resentment and 0 indicating lower levels of gender resentment. The inter-item correlation of the four measures ranges from .64 to .82 , and the Cronbach's alpha is .92. This measure is aggregated to the state level to create a mean level of state gender resentment. ${ }^{9}$

\section{RESULTS}

We examine whether gender resentment affects response to state-level social distancing orders using an ordinary least squares specification, with state and day random effects. ${ }^{10}$ This approach allows us to assume a different baseline of social distancing for each state and date. ${ }^{11,12}$

Figure 1 presents the marginal effects of stay-at-home-policies (SHP) on social distancing for three variables: states that voted for Trump in 2016, female governors, and female health directors, controlling for the

\footnotetext{
7. Home is measured as the common nighttime location of each mobile device over a six-week period to a Geohash-7 granularity.

8. Our results are robust to the inclusion of workers who are gone from their home for between three and six hours and six to ten hours in Table 5 in the online appendix.

9. Summary statistics are available in Table 2 in the online appendix.

10. Table 4 in the appendix presents the results from the regression analyses to assess the relationship between the gender of state-level officials and social distancing across various model specifications.

11. A Hausman test fails to reject the null, indicating that a random-effects model is appropriate.

12. Correlation between the variables is low, with gender resentment correlated at .22 with the state's vote for Trump and .14 with Republican governor (see Table 3 in the appendix).
} 

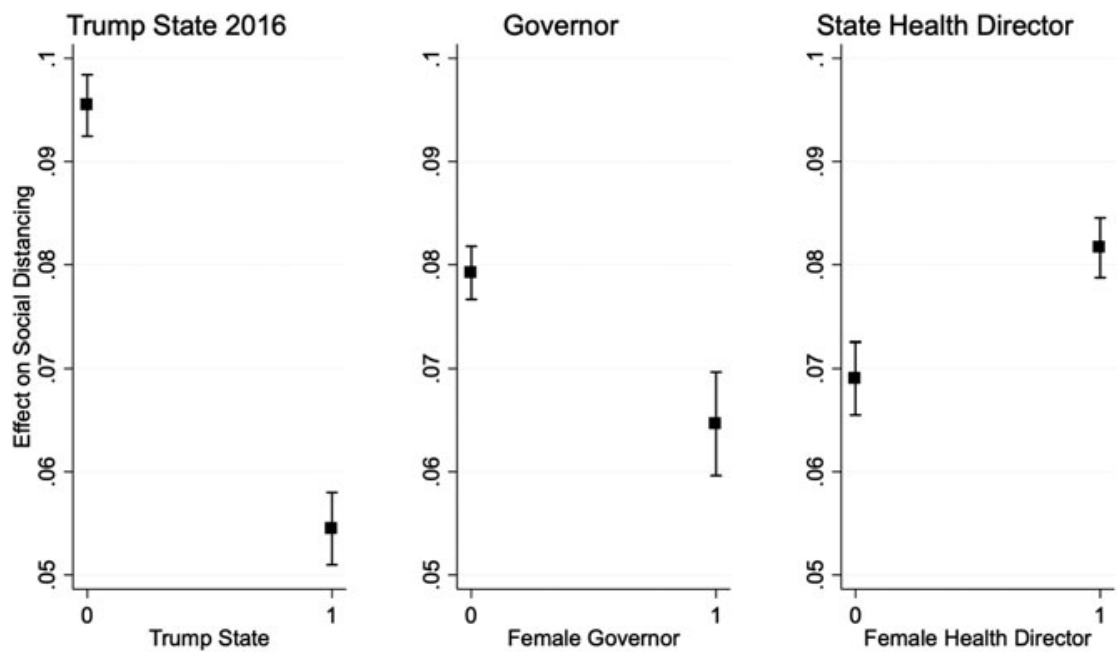

Figure 1. Marginal Effects of SHP on Social Distancing by State-Level Vairables.

Note: Model includes controls for 2016 state vote, lagged COVID-19 cases/ population, and the governor's party (see appendix Table 4).

governor's party affiliation and the one-week lag in COVID-19 cases by state/population. Figure 1 shows SHP have a lower effect in states that voted for Trump, even controlling for the governor's party and the virus's spread. These results are consistent with previous work suggesting that state-level support for Trump is associated with fewer people staying home (Painter and Qiu 2020). Interestingly, the effect of state policies is not consistent between female governors and health department directors, with policies having a negative effect on social distancing in states led by a female executive but a positive effect in states led by a female health director.

We explain this discrepancy by accounting for state-level gender resentment. Figure 2 presents the marginal effects of SHP on social distancing from a second model interacting gender resentment with the gender of the state leadership. ${ }^{13}$ Panel 1 presents the marginal effects of SHP on social distancing by the governor's gender. In states with lowlevel gender resentment, SHP increase social distancing behavior by about 6\%, with no significant difference between governors of different genders. However, as resentment increases, SHP become less effective in

13. The second model omits Vermont and Louisiana, as the data from the ANES measures did not include respondents from those states. 

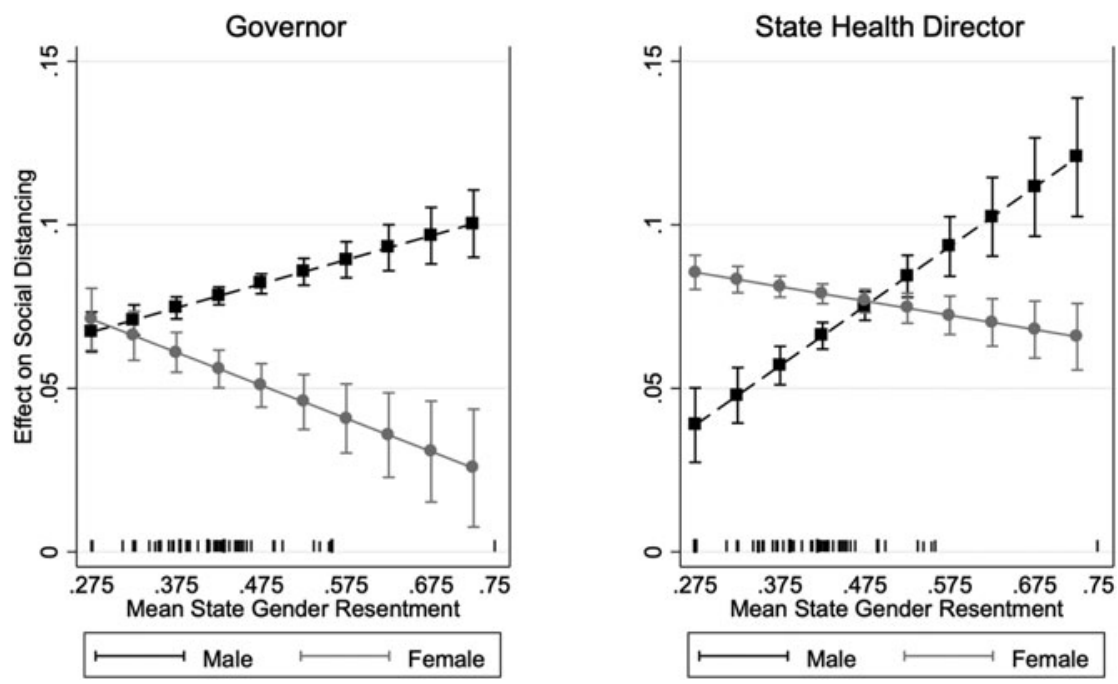

Figure 2. Marginal Effects of SHP on Social Distancing by State-Level Official Gender and Resentment.

Note: Model includes controls for 2016 state vote, lagged COVID-19 cases/ population, and the governor's party (see appendix Table 4). Rug plot shows the location of gender resentment.

states with a female governor but more effective in states with a male governor.

Panel 2 presents the marginal effects of SHP on social distancing by the director of the state health department's gender. In cases of low-level state gender resentment, stay-at-home policies have a greater effect on social distancing behavior in states with a female director; however, the effect decreases as gender resentment increases, with female state health directors' social distancing recommendations being least effective in states with high levels of gender resentment. Yet as resentment increases, male-led health department's policies become more effective than those of their female counterparts. ${ }^{14,15}$

14. Results hold when we omit Alaska, which has an aggregate state-level gender resentment of .75 (see Table 6 in the appendix).

15. The effect of gender resentment is linear, and results suggest that while the orders from female state health directors are more effective at the lowest levels of gender resentment, their orders become less effective as gender resentment increases. Future research could explore this relationship further. 


\section{CONCLUSION}

During a pandemic, leadership and expertise are critical. Yet gender resentment and hostile sexism can make citizens less willing to abide by the rules and recommendations from their elected and appointed leadership. As state-level gender resentment increases, citizen compliance with stay-at-home policies implemented by female leaders declines. This is not just true of elected officials; nonpartisan directors of health witness the same decline in compliance as governors, with stay-athome policies being less effective as gender resentment increases. However, when gender resentment is low female leaders are equally, if not more, efficacious, with no difference in the effect of SHP between male and female governors and a greater effect with female health directors. Here, gender resentment acts as an unseen barrier that mediates the efficacy of female leaders, even when society needs them the most.

Nicole Kalaf-Hughes is Associate Professor of Political Science at Bowling Green State University: ngkalaf@bgu.edu; Debra Leiter is Associate Professor of Political Science at the University of Missouri-Kansas City: leiterd@umkc.edu

\section{SUPPLEMENTARY MATERIAL}

To view supplementary material for this article, please visit https://oi.org/ $10.1017 / \mathrm{S} 1743923 \times 20000392$.

\section{REFERENCES}

Banks, Antoine J., and Nicholas A. Valentino. 2012. "Emotional Substrates of White Racial Attitudes." American Journal of Political Science 56 (2): 286-97.

Chen, M. Keith, and Ryne Rohla. 2018. "The Effect of Partisanship and Political Advertising on Close Family Ties." Science 360 (6392): 1020-24.

Glick, Peter, and Susan Fiske. 1996. "The Ambivalent Sexism Inventory: Differentiating Hostile and Benevolent Sexism." Journal of Personality and Social Psychology 70 (3): $491-512$.

Hetherington, Marc J., and Suzanne Globetti. 2002. "Political Trust and Racial Policy Preferences." American Journal of Political Science 46 (2): 253-75.

Jennings, Kent M. 2006. "The Gender Gap in Attitudes and Beliefs about the Place of Women in American Political Life: A Longitudinal, Cross-Generational Analysis." Politics \& Gender 2 (2): 193-219.

Kinder, Donald R., and Lynn M. Sanders. 1996. Divided by Color: Racial Politics and Democratic Ideals. Chicago: University of Chicago Press. 
Masser, Barbara, and Dominic Abrams. 2004. Reinforcing the Glass Ceiling: The Consequences of Hostile Sexism for Female Managerial Candidates. Sex Roles 51: 609-15.

Painter, Marcus O., and Tian Qiu. 2020. "Political Beliefs affect Compliance with COVID19 Social Distancing Orders.” http://dx.doi.org/10.2139/ssrn.3569098.

Shay, Laine. 2020. "Losing Time! Examining the Impact of Gender and Executive Branch Policymakers on the Timing of Stay-at-Home Orders" Gender \& Politics. In Press.

Valentino, Nicholas A., Carly Wayne, and Marzia Oceno. 2018. "Mobilizing Sexism: The Interaction of Emotion and Gender Attitudes in the 2016 US Presidential Election." Public Opinion Quarterly 82 (S1): 799-821.

Wallsten, Kevin, Tatishe Nteta, Lauren McCarthy, and Melinda Tarsi. 2017. "Prejudice or Principled Conservatism? Racial Resentment and White Opinion toward Paying College Athletes" Political Research Quarterly 70 (1): 209-22. 